\title{
INTEREST RATE RISK OF BANKING SECTOR: THE EFFECT OF MATURITY GAP ON NET INTEREST INCOME IN INDONESIA
}

DOI: 10.17261/Pressacademia.2019.1025

JEFA- V.6-ISS.1-2019(2)-p.19-31

\section{Andewi Rokhmawati}

Universitas Riau, Faculty of Economics and Business, Kampus Binawidya UNRI Jl. Subrantas Km 12.5 Pekanbaru, Riau, Indonesia. Andewi.Rokhmawati@lecturer.unri.ac.id , ORCID: 0000-0003-3713-972X

Date Received: January 13, 2019

Date Accepted: March 20, 2019

To cite this document

Rokhmawati, A. (2019). Interest rate risk of the banking sector: the effect of maturity gap management on net interest income in Indonesia. Journal of Economics, Finance and Accounting (JEFA), V.6(1), p.19-31.

Permemant link to this document: http://doi.org/10.17261/Pressacademia.2019.1025

Copyright: Published by PressAcademia and limited licenced re-use rights only.

\section{ABSTRACT}

Purpose - This study aims to examine how the interest rate risk management that has been reflected in banks' maturity gaps affect the net interest income (NII).

Methodology - The population in this study is all conventional commercial (non-Sharia) banks in Indonesia as many as 99 banks. Of the 99 banks, 57 banks were selected as the sample of in the study. Determination of the sample is based on these criteria: the availability of the bank's annual report containing financial statements providing data about the descriptions of interest rate risk management, which also provides complete data about bank's RSA and RSL from 2013 - 2017. There are five years of the research period, so 285 unit observations are used in the analysis. The study employs multiple regression analysis with panel data. Net interest income is derived from the difference between interest income and interest expense. The maturity gap is calculated as the difference between RSA and Risk RSL. The study uses a dummy variable of IRS, LDR, net NPL and ownership status of banks.

Findings - The results of the study show that maturity gap has a negative effect on NII and banks with positive gaps have higher NII than banks with negative gaps. These results imply that when the interest rate decreases, the widened positive gap will lower NII.

Conclusion - The conclusion of the research is that in conditions of declining interest rates, the more positive gap between RSA and RSL has decreased banks' NII. The practical implication of the results is that banks need to think about lowering the RSA by means of managing their assets, such as banks need to buy long-term securities, extend the loan maturity, and change the interest rate from the floating rate to a fixed rate. In terms of management liabilities, banks need to think about increasing RSL by giving premium interest rates for deposits with a maturity of less than one year, and by borrowing funds at fair interest rates.

Keywords: Indonesian banks, interest rate risk, interest rate sensitivity, maturity gap, net interest income.

JEL Codes: E43, G21, M21

\section{INTRODUCTION}

Adequate capital is not the only prerequisite for banks to be able to cope with pressure at crisis time. This was demonstrated by the experience during the period of the global financial crisis in 2007/2008 which was marked by the collapse of major financial institutions in the United States and the UK, which had strong capital, such as: Lehman Brothers, American International Group (AIG), Merrill Lynch, Morgan Stanley, Citigroup, UBS, Fannie Mae, Freddie Mac, and others (Acharya, Cooley, Richardson, \& Walter, 2011). The collapse of this large financial institution has a systemic impact on the business world throughout the world, including Indonesia. This slowdown economic growth has still been felt today. The uncertainty of global economic conditions puts pressure on Indonesia's economic growth (Budoyo, 2017).

To drive the level of economic growth, various policies are taken by the Indonesian Government whose goal is to encourage improvements in the investment climate. The policy is to simplify investment permits in order to accelerate the period of processing permits. The policy is also enabled investors to get fiscal incentives such as tax allowances, tax holidays, and tax rate cuts in certain sectors. The government's efforts gain good momentum when UNCTAD in its latest report "2016 World Investment Report" places Indonesia as the third country of foreign direct investment (FDI) goals (Budoyo, 2017). This rating is better than the previous year, which was ranked the fifth. 
FDI investment in Indonesia grew 46\% in January-July 2016 from $\$ 19.4$ billion in 2015 to $\$ 28.0$ billion in 2016 (Budoyo, 2017). Likewise, investment in domestic investment has increased from year to year. Meanwhile, Bank Indonesia is also consistent with optimizing the domestic economic recovery while maintaining macroeconomic stability, amidst uncertain global financial markets, namely by lowering the BI rate. Figure 1 below illustrates the development of domestic investment and the $\mathrm{BI}$ rate growth.

Figure 1: The Development of Domestic Investment Realisation (in Billion Indonesian Rupiah, IDR) and Indonesian Central Bank (BI) Rate from $2012-2017$

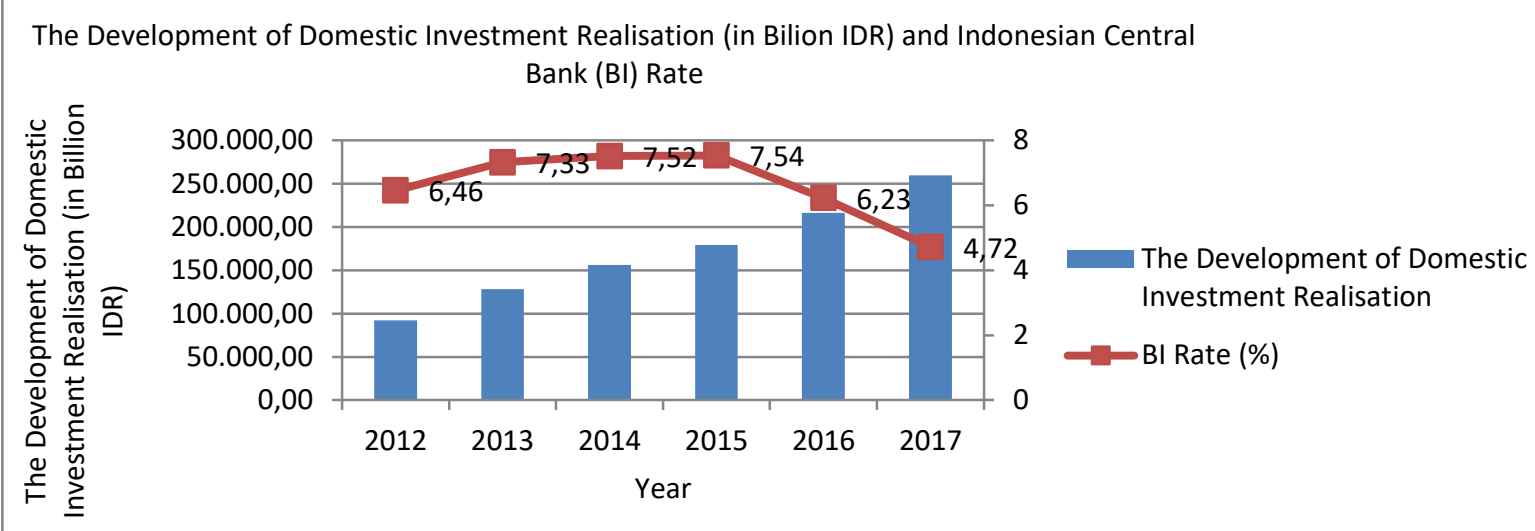

Source: Bank Indonesia, 2017 and BPS, 2017

From Figure 1, it can be seen that government policies in creating an investment climate show results which are proven by an increase in domestic investment realization from year to year. The increase in the value of this investment was supported by a decrease in the BI rate, which was followed by a decrease in loan interest rates. The increase in investment value was also accompanied by an increase in the number of distributed loans by banks to finance the investment and by an increase in third-party funds collected by Indonesian banks. The data can be seen in Figure 2 below.

As known from Figure 2, the activities of rising funds (funding activities) and distributing funds (lending activities) by Indonesian commercial banks have increased. However, the increase in fund collecting activities and fund distributing activities is not automatically followed by the increase in Net Interest Margin (NIM) or Return on Assets (ROA). NIM is the ratio between net interest incomes divided by productive assets. Although the NIM has increased from 2014 to 2016 , in 2017 it has decreased. Likewise, ROA has a downward trend. ROA measures the company's ability to generate profits before interest and taxes on assets used (Bank-Indonesia, 2001). The decrease in these ratios indicates that there is a decrease in the ability of the banks to manage the funds distributed and the funds raised from the community due to the decline in interest rates.

Management of funds distributed and funds collected from the community is known as Asset Liability Management (ALM) (Byrne, 2000). ALM gets the most attention from banks because of uncertainty and volatility in the market and the unpredictable influence of domestic and global market forces. This condition can reduce bank assets. ALM is an integrated approach towards the effective balance sheet management that can be achieved through restructuring the portfolio of assets and liability portfolios that are appropriate from time to time. In today's rapidly changing market environment, ALM is important (Byrne, 2000). The main objective of ALM is to manage net interest income in such a way that the level and risk align with the company's risk-return objectives. This technique does not eliminate risk but tries to manage it in such a way that fluctuations in net interest income are minimized in the short term and the long-term survival of the organization is achieved. 
Figure 2: Development of Funds Distribution (Billions of Rupiah), Collection of Third Party Funds (Billions of IDR), ROA, and NIM, 2012-2017



Source: OJK, $2017 a$

Efficient interest rate risk management is an important activity of banks in maximizing their income while controlling risk exposure. Thus, evaluating the bank's resilience to the risk exposure of interest rate changes is very important. This is because of the vulnerability of banking operations to the risk of external pressure. This pressure will ultimately affect the interest rate that must be set for lending and funding activities and affect the level of liquidity that the bank must maintain.

There are many studies that analyze interest rate risk. Most of them are related to identifying determinants of interest rate risk (Ahmed, Beatty, \& Takeda, 1997; Esposito, Nobili, \& Ropele, 2015; Holston, Laubach, \& Williams, 2017; Rachel \& Smith, 2015). As a result of the studies, they suggested several strategies to reduce interest rate risk. In addition, other studies also concluded that interest rate risk must be managed together with credit and liquidity risks (Esposito, et al., 2015; Singh, 2013).

Furthermore, other researchers analysed the gap management between RSA and RSL from several individual banks. Without doing a statistical procedure test, they provide a descriptive analysis that explains how the gap between RSA and RSL of several individual banks and compares one bank to another bank. Then, they provide recommendations that should be done by banks, see (Baser, 2014; Meena \& Dhar, 2014; Prathap, 2013; Singh, 2013).

In the absence of statistical testing, this means that the results of the studies are only applied to the individual bank that is being observed. Furthermore, the results of the analysis cannot be used for generalisation purposes. Meanwhile, it has been still rare research analysing how the RSA and RSL gap management influence the NII. Thus, this study aims to examine how the interest rate risk management that has been implemented by banks affect the net interest income (NII). Management of interest rate will be measured with Interest Rate Sensitivity (IRS) and with the gap between rate sensitivity assets (RSA) and rate sensitivity liability (RSL). The research gap will be filled by this research. The next contribution is that this research will also analyse how the NII of banks with a positive gap responds to the decline of the interest rate. This study includes control variables: NPL, LDR, and dummy variables of three bank ownership status, namely conventional banks owned by the government, national private banks, and foreign banks operating in Indonesia. This grouping aims to see how the risk management of each bank group has an impact on their NII. Which group that has the highest NII. This study will also include a dummy variable of years covering the period time of the study to consider how NII of each year.

The paper proceeds as follows. Section 2 presents the literature review underpinnings of the study and the hypothesis development. Section 3 describes the data and methodology. Section 4 presents findings and discussions. The last section provides the conclussion.

\section{LITERATURE REVIEW}

\subsection{Gap Sensitivity to Interest Rate Change}

The intermediary function is still the most important type of banks' business (Doran \& Fitzpatrick, 2003). This intermediary function makes banks vulnerable to interest rate risk exposure because of a gap in the maturity or duration when banks borrow and lend (Murphy, 2013).

Kuncoro and Suhardjono (2004) stated that interest rate risk refers to the risk posed by changes in interest rates that have a direct impact on interest earned from lending activities and interest paid for financing activities. Interest rate risk is about managing the net interest margin (interest income reduced by interest costs) and controlling the risk caused by changes in 
interest rates. They also stated that when there is a change in interest rates, banks can control interest rate risk by matching asset maturity and liability maturity. If the assets and liabilities have the same maturity, the bank will be able to maintain a net interest margin because the increase or decrease in interest costs and interest income occur simultaneously.

However, the reality of the market is such that the bank cannot balance the maturity of assets and liabilities. A decrease in interest rates will benefit the bank. Conversely, an increase in interest rates will harm the bank. This happens when banks finance long-term loans with short-term deposits (Mishkin \& Eakins, 2012). Bank risk is increasingly difficult to assess because of the nature of the loan portfolio held by banks and derivative transactions that they trade in financial markets (J.P.Morgan, 1997). Interest rate risk is the main risk that must be managed by banks because it has an impact on potential costs and income deviations (Djohanputro, 2004).

Furthermore, Djohanputro (2004) said that management's preventive action in controlling interest rate risk can be conducted by implementing Asset Liability Management (ALM). ALM is basically the coordination of reciprocity that is carried out in an integrated manner between the two sides of the bank's balance sheet based on plans and short-term decisions (Siamat, 2004).

The main function of ALM according to Djinarto (2000) is used to structuring asset and liability in order to optimise NII and to achieve stable growth. One of which is through gap management. Interest rate risk measurement is an activity that must be carried out by the bank to see how much potential loss will be borne by the bank (Djohanputro, 2004). The interest rate risk measurement technique commonly used by banks is gap analysis (Esposito, et al., 2015). This method requires a price gap report of asset sensitive to changes in interest rates based on their maturity distributions, and a gap report of liabilities sensitive to changes in interest rates based on their maturity distributions. These reports are provided off the balance sheet. Assets and liabilities that do not have intervals or time periods for re-signing contracts are assigned to the maturing list based on statistical analysis or valuation.

Interest rate risk is measured by calculating maturity gaps. The gap is defined as the absolute difference between the rate of sensitive assets (RSA) and the rate of sensitive liabilities (RSL) (Vij, 2005). Signs and the magnitude of the gap at various times can be used to assess the potential volatility of income arising from the changes in interest rates. A positive gap indicates that RSA is more than RSL and from an income perspective; this position benefits the bank in the event of an interest rate increase. The negative gap indicates that the RSL is more than RSA and from an income perspective; this condition will benefit the bank if there is a decrease in interest rates (Vij, 2005). Banks must manage the gap between RSA and RSL because the wider the gap, the riskier the bank against interest rate changes. The wider the gap, the more sensitive the NII of the bank is to interest rate changes. The gap is a measure of the sensitivity of net interest income in relation to interest rate changes (Koch \& Macdonald, 2003; Riyadi, 2006). In brief, if the bank wants to keep its net interest income immune from changes in interest rates, it must monitor and manage the gap carefully. Net interest income is the difference between interest income and interest expense.

\subsection{Hypothesis Development}

Indonesia as a country with an open economy could be affected by global economic pressures and the global crisis. The crisis variables affect the Indonesian economy, especially through the banking industry interest rate changes. The function of banks is an intermediary that channel public funds to other parties that need funding. In carrying out the intermediary function, banks faced with various uncertainty conditions. Interest rates are one of the market variables that are very influential on the bank.

Banks are businesses whose profits are based on spread-based income and fee-based income, where the benefits are derived from the difference in fees for lending and funding interest, as well as fees obtained for services provided. So that changes in interest rates will affect bank income. The benchmark interest rate in Indonesia is the interest rate of Bank Indonesia Certificates (SBI). SBI is used as an instrument to control the level of market liquidity, inflation rates, and overall macroeconomic conditions. Policy changes set by Bank Indonesia will affect the direction of SBI movements. SBI interest rates become a reference for other domestic interest rates so that changes in SBI interest rates will affect other domestic interest rates.

The increase in SBI interest rates will also lead to an increase in deposit, and credit interest rates directly, where an increase in loan interest rates will move slower than deposit rates. When market interest rates increase and banking competition gets tighter, banks will increase their deposit rates to keep their customers. This is done because customer deposits are the largest source of funds to finance banks' productive assets. An increase in deposit interest rates will increase the cost of funds so that the bank will increase its lending rates. The increase in lending rates will cause changes in bank assets, especially from credit position, both working capital loans, investment loans, and consumer loans. The increase in deposit rates will also cause changes in the position of bank liabilities, especially from time deposits, demand deposits and savings accounts. Assets and liabilities changes in a contradicting direction will cause a gap between the two sides, where the gap will affect the bank's profitability along with changes in market interest rates. 
Changes in SBI interest rates also have an impact on changes in people's preferences in terms of investing in deposits, as well as investing in other financial instruments because SBI is considered a risk-free interest rate. Therefore, in the bank balance sheet position, there are categories of assets and liabilities that are sensitive to interest rate changes. So, the change in interest rates will affect the position of assets and liabilities of the bank, which will ultimately affect the profit of the bank. This can be caused by the mismatch between the maturity of RSA and the maturity of RSL of the banks.

The impact of the above risks can be managed using the Asset and Liability Management (ALM) approach and the method of sensitivity gap management. The purpose of sensitivity gap management is to adjust assets and liabilities so that the source of funding and the uses of funding are able to produce predetermined spreads and get the same maturing. By managing assets and liabilities through the ALM approach, it is expected that the spread between income and risk can be maintained so that changes in the value of sensitive assets and liabilities can be anticipated to prevent losses. Based on the gap analysis that has been done, it will be known how the potential increase of NII is. Based on the explanation above, the hypothesis can be drawn:

Ha1: Gap between RSA and RSL has a significant effect on NII.

Ha2: Banks with a positive gap (RSA and RSL) have a different NII with banks with a negative gap

Based on the gap analysis, it will be known how the potential of NII improvement, so that it can be recommended the right strategy to anticipate the risk of interest rate changes in the next period.

\section{DATA AND METHODOLOGY}

The population in this study is all conventional (not Sharia) commercial banks in Indonesia as many as 99 banks. Of the 99 banks, 57 banks were selected as the sample of in the study. Determination of the sample is by using purposive sampling, based on the following criteria:

a. The bank is a conventional commercial bank (non-sharia) operating in Indonesia. The reason is that sharia banks do not adopt an interest rate in their business practices.

b. Availability of the bank's annual report that contains financial statements and presents data about the descriptions of interest rate risk management, which also provides complete data about bank's RSA and RSL from 2013 - 2017.

There are five years of the research period, so there are 285 unit observations used in the analysis.

\subsection{Net Interest Income}

Net Interest Income (NII) is the bank's performance ratio that measures how much the company benefits from the bank's operational activities as a mediator, namely lending and funding activities. NII is the difference between interest income gained from lending activities that are subtracted with interest costs of collecting funds activities (funding activities) from the third parties (Winarso \& Salim, 2017). Net interest income is derived from the difference between interest income and interest expense.

$\mathrm{NII}=$ Interest Income - Interest Expense

\subsection{Gap Sensitivity}

The sensitivity-gap analysis measures assets and liabilities that are sensitive to changes in interest rates. The steps in the sensitivity gap analysis are as follows:

\section{Compile Mismatch-Rate Sensitivity}

Compile Mismatch-Rate Sensitivity by grouping re-pricing/maturity schedule, namely the preparation of assets and liabilities based on the determination of new interest rates and based on maturity, and asset grouping (RSA) and liabilities (RSL) based on their sensitivity (Ali, 2004). This data has been provided in the bank's annual report on interest rate risk management.

Rate Sensitive Assets (RSA) are all assets, including fixed rate assets, which have a short-term maturity of less than 1 year or assets with a floating interest rate which must be renewed every 1 month, 3 (three) months, 6 (six) months, and a maximum of 1 year.

Liabilities classified as rate sensitive liabilities (RSL) are all liabilities, including fixed rate liabilities, which have a maturity of not more than 1 year, or loans with floating interest that must be renewed every 1 month, 3 (three) months, or 6 (six) months, or no more than 1 year. 


\section{Perform Risk analysis}

Risk analysis is done by calculating the gap sensitivity to interest rate changes which are proxied by the interest sensitivity ratio (interest rate sensitivity, IRS) with the following formula (Ali, 2004):

$I R S=\frac{R S A}{R S L}$

This calculation is used to determine the comparison between RSA and RSL. The IRS $>1$ means that RSA $>$ RSL, whereas IRS $<1$ indicates that RSA < RSL. This IRS value is used to measure the sensitivity of NII to the interest rate. An analysis of gap that occurs due to interest rate changes is done by calculating the difference between RSA and RSL, which is formulated as follows:

Gap = RSA - RSL,

Where:

RSA = Rate Sensitive Asset (in Indonesian Rupiah, IDR)

RSL = Rate Sensitive Liabilities (in IDR)

This calculation is to classify between banks that have a positive gap with a negative gap. Banks with a positive gap are given a value of one and banks with a negative gap are given a value of zero.

\subsection{Control Variables}

The research includes several control variables as follows

1. Non-Performing Loans (NPL) show how much the level of non-performing loans is from the total amount of loans disbursed (Winarso \& Salim, 2017). NPL includes less successful collectability, doubtful, and bad debt. The decreasing total NPL shows the decreased effectiveness of banking performance in credit management and vice versa. The higher the NPL will affect the NII because the creditors are unable to pay off the interest or principal of the loan with the bank.

2. Loan to Deposit Ratio (LDR) is an indicator ratio to determine bank liquidity. This ratio measures a bank' ability to fulfill its obligations (Winarso \& Salim, 2017). LDR is the ratio between the total amounts of credit given by the bank divided by the funds received by the bank. The LDR implies how strong the bank's ability to repay funds-withdrawal by depositors by controlling the credit provided in which these depositors' savings are the sources of banks' liquidity. The higher the LDR reflects the lower level of liquidity. The higher LDR means the higher third-party funds are distributed to debtors. Logically, if there is a change in interest rates, the bank will adjust the interest rate on lending and funding. This change in lending and funding interest rates will affect NII. This magnitude of changes in the NII is related to how the bank manages its RSA and RSL.

3. Banks are grouped based on bank ownership status: Owned by the Government (central government ownership or local government ownership), National Private Bank, and Foreign Bank. The purpose of this grouping is to find out the difference in risk management of interest rate changes. Considering, each ownership status has characteristics in terms of corporate culture in responding to risk, it is interesting to analyze banks' NII; whether banks with different corporate culture have different $\mathrm{NII}$ in responding to interest rate risks. This variable will be measured by a dummy variable, where the ownership of the government banks will be used as a baseline. So there will be two dummy variables. The measurement of the dummy variable is as follows:

a. The first dummy variable is a national private bank, the bank with a national private ownership status will be assigned with a value of one and the status of the other bank is given a value of zero.

b. The second dummy variable is a foreign bank, the bank with foreign ownership status will be assigned with a value of one and the status of the other bank is given a value of zero.

4. This study also looks at how the development of NII every year. This variable will be measured by a dummy variable, where the year 2013 will become the baseline. So there will be four dummy variables. The assessment of the dummy variable is as follows:

a. The first dummy variable is the year 2014, then the year 2014 is given a value of one and the other years are given a value of zero.

b. The second dummy variable is the year 2015, then the year 2015 is given a value of one and the other years are given a value of zero. 
c. The third dummy variable is the year 2016 , then the year 2016 will be given a value of one and the other years are given a value of zero.

d. The fourth dummy variable is the year 2017, then the year 2017 will be given a value of one and the other years are given a value of zero.

A regression model for the relationship between the management sensitivity of the RSA gap and RSL with the NII can be developed as follows:

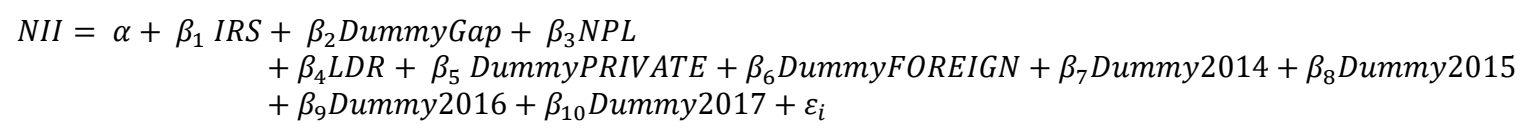

Where,

$\begin{array}{ll}\alpha & : \text { Constant variables } \\ \beta_{1}-\beta_{10} & \text { : Regression coefficient } \\ \text { NII } & : \text { Net interest income } \\ \text { IRS } & \text { : Interest rate sensitivity } \\ \text { DummyGap } & : \text { Dummy variable difference between RSA and RSL } \\ \text { NPL } & : \text { Non-performing Loan } \\ \text { LDR } & \text { : Loan to Deposit Ratio } \\ \text { DummyPRIVATE } & : \text { Dummy variable status of national private banks } \\ \text { DummyFOREIGN } & \text { : Dummy variable status of a foreign-owned bank } \\ \text { Dummy2014 } & : \text { Dummy variable of the year } 2014 \\ \text { Dummy2015 } & \text { : Dummy variable of the year } 2015 \\ \text { Dummy2016 } & : \text { Dummy variable of the year } 2016 \\ \text { Dummy2017 } & : \text { Dummy variable of the year } 2017 \\ \varepsilon_{\mathrm{i}} & : \text { Error term }\end{array}$

\subsection{Classical Assumption Tests}

The classic assumption test that underlies a multiple regression model is done to get an accurate model. The classic assumption tests in this study consist of residual normality, multicollinearity, heteroscedasticity and autocorrelation (Ghozali, 2013; Hair Jr, Black, Babin, \& Anderson, 2010). The result is provided in the appendix.

\section{FINDINGS AND DISCUSSIONS}

After the regression models passed from the normality, multicollinearity, heteroscedasticity, and autocorrelation tests (the results of the series tests can be seen in Appendix), a regression analysis can be conducted. The regression result can be seen as follows.

\subsection{Findings}

To smooth the data so that the data has a normal distribution, this research transforms the data of NII, into the natural log (Ln) form. The descriptive statistics can be seen in Table 1. Descriptive statistics showed in Table 1 do not provide data of dummy variables. This is because a dummy variable is only to dichotomize one group with other groups. It does not have the value of mean, minimum, maximum, neither std. deviation.

Table 1: Descriptive Statistics

\begin{tabular}{|l|c|c|c|c|c|}
\hline & N & Minimum & Maximum & Mean & Std. Deviation \\
\hline NII & 285 & 23.0330 & 30.5897 & 26.7348 & 1.3830 \\
IRS & 285 & 0.2154 & 2.2062 & 1.2421 & 0.2908 \\
NPL & 285 & 0.0000 & 0.9360 & 0.9180 & 0.0548 \\
LDR & 285 & 0.4225 & 1.9696 & 1.0154 & 0.1306 \\
Valid N (listwise) & 285 & & & & \\
\hline
\end{tabular}

Source: computed data based on the data collected

The statistical test of regression analysis with panel data has been performed and the result can be seen in Table 2 . 
Table 2: Results of Statistical Tests

Model Summaryb

\begin{tabular}{|c|c|c|c|c|c|}
\hline Model & $\mathrm{R}$ & R Square & Adjusted R Square & Std. Error of the Estimate & Durbin-Watson \\
\hline 1 & $.705^{\mathrm{a}}$ & .497 & .479 & .99831365 & 2.127 \\
\hline
\end{tabular}

a. Predictors: (Constant), Y2017, FOREIGN, NPL, IRS, Y2014, GAP, LDR, Y2015, PRIVATE, Y2016

b. Dependent Variable: NII

ANOVA $^{a}$

\begin{tabular}{|c|c|c|c|c|c|}
\hline Model & Sum of Squares & df & Mean Square & $\mathbf{F}$ & Sig. \\
\hline Regression & 270.103 & 10 & 27.010 & 27.102 & $.000^{\mathrm{b}}$ \\
\hline 1 Residual & 273.077 & 274 & .997 & & \\
\hline Total & 543.180 & 284 & & & \\
\hline
\end{tabular}

a. Dependent Variable: NII

b. Predictors: (Constant), Y2017, FOREIGN, NPL, IRS, Y2014, GAP, LDR, Y2015, PRIVATE, Y2016

Coefficients $^{\mathrm{a}}$

\begin{tabular}{|c|c|c|c|c|c|c|c|c|c|}
\hline \multirow{2}{*}{ Model } & \multicolumn{2}{|c|}{$\begin{array}{c}\text { Unstandardized } \\
\text { Coefficients }\end{array}$} & \multirow{2}{*}{$\begin{array}{c}\text { Standardized } \\
\text { Coefficients } \\
\text { Beta }\end{array}$} & \multirow{2}{*}{$\mathbf{T}$} & \multirow{2}{*}{ Sig. } & \multicolumn{2}{|c|}{$\begin{array}{c}90.0 \% \text { Confidence } \\
\text { Interval for B }\end{array}$} & \multicolumn{2}{|c|}{ Collinearity Statistics } \\
\hline & B & $\begin{array}{l}\text { Std. } \\
\text { Error }\end{array}$ & & & & $\begin{array}{l}\text { Lower } \\
\text { Bound }\end{array}$ & $\begin{array}{l}\text { Upper } \\
\text { Bound }\end{array}$ & Tolerance & VIF \\
\hline 1 (Constant) & 26.639 & 1.185 & & 22.472 & .000 & 24.682 & 28.595 & & \\
\hline IRS & -.413 & .224 & -.087 & -1.844 & .066 & -.782 & -.043 & .828 & 1.207 \\
\hline GAP & .295 & .150 & .089 & 1.959 & .051 & .046 & .543 & .899 & 1.112 \\
\hline NPL & .096 & 1.102 & .004 & .087 & .931 & -1.722 & 1.914 & .964 & 1.038 \\
\hline LDR & .884 & .500 & .083 & 1.766 & .079 & .058 & 1.710 & .822 & 1.217 \\
\hline PRIVATE & -2.025 & .144 & -.732 & -14.052 & .000 & -2.263 & -1.787 & .676 & 1.480 \\
\hline FOREIGN & -.689 & .157 & -.224 & -4.377 & .000 & -.948 & -.429 & .700 & 1.429 \\
\hline Y2014 & .156 & .187 & .045 & .834 & .405 & -.153 & .465 & .624 & 1.602 \\
\hline Y2015 & .311 & .188 & .090 & 1.660 & .098 & .002 & .621 & .621 & 1.609 \\
\hline Y2016 & .512 & .188 & .148 & 2.729 & .007 & .202 & .822 & .621 & 1.611 \\
\hline Y2017 & .677 & .189 & .196 & 3.582 & .000 & .365 & .988 & .612 & 1.633 \\
\hline
\end{tabular}

a. Dependent Variable: NII

From Table 2, a research model can be formulated as follows:

$$
\begin{aligned}
N I I=26.639- & 0 \\
& 413 \text { IRS }+0.295 \text { DummyGap }+0.096 N P L \\
& +0.884 L D R-2.025 \text { DummyPRIVATE }-0.689 \text { DummyFOREIGN }+0.156 \text { Dummy } 2014 \\
& +0.311 \text { Dummy } 2015+0.512 \text { Dummy } 2016+0.677 \text { Dummy } 2017+\varepsilon_{i}
\end{aligned}
$$

\subsection{Discussions}

\subsubsection{The Effect of Interest Rate Sensitivity (ISL) on NII}

Interest rate sensitivity (ISL) is measured by comparing RSA divided by RSL. When ISL value is equal to one, it means that RSA is equal to RSA that it is called a zero gap. The ISL value is more than one meaning that the RSA is greater than RSL that it is known as a positive gap. Conversely, the ISL value less than one means that RSA is smaller than RSL that it is known as a negative gap (Ali, 2004).

From Table 2, it can be seen that IRS has a negative and significant effect on NII. It means that the increase in IRS will decrease NII. Based on the research model above, it can read that when the value of other independent variables are constant, a one percent increase in IRS will decrease NII by 0.413 percent and the effect is significant at the confidence level of 90 percent. The negative relationship means that the more positive gap between RSA and RSL, the lower NII or the more negative gap between RSA and RSL, the higher NII. The negative relationship means that the gap between RSA and RSL has the opposite direction from the NII.

The positive gap indicates that assets sensitive to interest rates are greater than the liabilities sensitive to interest rates (RSA > RSL). As it is known that from 2013 to 2017, there is a decreasing trend in the interest rate. When there is a decreasing trend in interest rate, a positive gap between RSA and RSL will decline. This decrease in NII was due to a decline in income that was faster than a decrease in funding costs (Riyadi, 2006). 
This condition provides several indications: first, banks are likely to conduct lending activities in RSA that provide fluctuating income or distributing credit by setting interest based on market interest (floating rate). Thus, in the event of a decrease in SBI interest, the interest earned by the banks from their lending activities will decrease. On the other hand, the banks might finance their majority assets (RSA) from a fixed source of funds (RSL). Thus, when a decrease in SBI interest rates occurs, the banks cannot immediately respond to the decrease in SBI interest and cannot immediately decline its saving interest. In brief, the decline in SBI causes interest income from bank lending activities to decline, but this is not followed by a decrease in interest rates on liabilities because the interest rate on liabilities is fixed rate, so that NII experiences a decline.

Second, many banks might have a portfolio in short-term securities. On the other hand, the banks might carry out a portfolio financing strategy that is derived from long-term financing sources. The difference in the maturity of asset and liabilities will result in changes in income and costs. The bank cannot immediately and simultaneously implement a strategy to achieve the desired gap in accordance with the desired strategy.

Third, it seems that the positive gap between RSA and RSL is that liabilities widely spread over the maturity tenor at less than one year. A positive gap indicates that assets that are soon due are partly financed by long-term funding. The spread of maturity of assets, which are in less than one year, indicates that many bank investments (assets) are soon due. This means that the source of income has ended up flowing; on the other hand, some of the funding sources come from the source of long-term funds that the banks still have to pay interest. This is what makes the negative relationship between the positive gap of RSA_RSL and NII when the SBI interest rate decreases.

The implication of this result is that banks need to think about steps to reduce RSA and increase RSL. Kuncoro and Suhardjono (2004) suggest various ways for banks to reduce RSA by buying long-term securities, extending loan maturity, and changing the interest rate from a floating rate to a fixed rate. While the way to increase RSL is by giving premium interest rates for deposits with a maturity of less than one year and borrowing funds with a reasonable interest rate.

\subsubsection{The Effect of Bank Gap Status (Positive Gap or Negative Gap) on NII}

Positive gap or negative gap is proxied as a dummy variable, where banks with positive gaps are given a value of one and the bank with a negative gap is given a zero value. From Table 2, it can be seen that the estimation of DummyGap is 0.295. It means that banks with a positive gap will have a higher NII than banks with negative gap. Banks with positive-gap will have NII 0.295 higher than the NII of banks with negative-gap.

This statistical result seems to contradict with the statistical results of the effect of ISL on NII. Where, when the SBI interest rate decreases, the more positive RSA and RSL gap, the lower the NII. The statistic results indicate that banks that have a positive gap and RSL will experience a decrease in NII. However, this condition is not supported by the statistical results provided in Table 2. Banks that have a positive gap turn out to have a higher NII than banks with a negative gap.

The above conditions could be caused by the following explanation. First, even though the bank's NII with a positive gap experienced a decline and the bank's NII with a negative gap experienced an increase, it seems that the bank's NII with a positive gap is still higher than the bank's NII with a negative gap. This may be because through UU No 23/2014 about good corporate governance for state-owned banks that require the banks to meet the guidelines provided the government. The guidelines include that banks should report their performance and level of risks (Kementerian-Dalam-Negeri, 2017; OJK, 2017b).

Second, measuring NII with IDR nominal value may contain weaknesses. Banks with positive gaps have a higher nominal NII compared to banks that have a negative gap. This NII is calculated from the difference between interest incomes minus interest costs. When a bank group with a positive gap consists of banks with large total assets, it is natural that the nominal $\mathrm{NII}$ is also large. On the contrary, when the bank group with a negative gap consists of banks with smaller total assets, then a smaller NII nominal is also a natural thing. This weakness is a note for improvement in future research.

\subsubsection{Control Variables}

Net non-performing loans (net NPLs) of banks do not have a significant effect on the NII. The insignificant effect may be because the average level of net NPL is very low at $0.918 \%$ (see Table 1 ) when this figure is compared to $2 \%$, the net NPL requirement of the Indonesian Financial Services Authority (OJK, 2017b). Because banks are able to maintain their net NPL below $2 \%$ at least in a period time of this study, the net NPLs do not have a significant effect on NII.

Loan to deposit ratio (LDR) has a positive and significant impact on the NII at a $90 \%$ confidence level. The higher the LDR will increase the NII. This is because bank interest income is obtained from credit distributed, in which the funds are collected from the third parties and communities. The greater the credit distributed, the greater the bank's interest income. The mean of banks' LDR included in the sample is $101.54 \%$, while the regulations set the LDR should be in between $80 \%$ and $92 \%$ (OJK, 2017b). LDR above $100 \%$ means that banks are categorized as less liquid. This bank finances its credit using call money, where call-money is a source of short-term loan funds that have high costs. 
The national private bank group has a lower $2.025 \% \mathrm{NII}$ compared to the government-owned NII bank. Furthermore, the NII of foreign banks is $0.689 \%$ lower than the NII of state-owned banks. Government-owned banks have a higher NII than other ownership, probably due to the presence of state-owned banks classified as large banks. Hence, a higher NII nominal makes that this condition is normal for bigger banks to have higher NII than those smaller banks. This nominal measurement of NII may have to be corrected due to homogeneity problems.

Finally, the NII of the year 2014 was higher than the NII of the year 2013. When viewed from the beta coefficient value of each year, the beta value is positive and from year to year it increases. This means that from 2013 to $2017 \mathrm{NII}$ banks experienced an increase. This is contradictory with the real data of NIM that from 2014 to 2016, the NIM has increased, but in 2017 the NIM has decreased. So, this means that the measurement of the gap by using the nominal IDR value of NII may contain weaknesses in terms of homogeneity. In the sense that a large NII nominal does not necessarily reflect the performance of efficient lending and funding activities if the performance also considers the amount of credit disbursed and the total assets owned by the banks. So, it needs to be reviewed for measuring the variable in the ratio scale.

\section{CONCLUSION}

From the above explanation, it can be concluded that in conditions of declining interest rates, the enlarged positive gap between RSA and RSL has decreased banks' NII. Based on these results, logically, in the condition of declining interest rates, banks that have a positive gap should have a lower NII than the bank with a negative gap. But the empirical results do not support this statement. Even, banks with positive gap have higher NII than banks with a negative gap.

The practical implication of the results is that under the condition of decreasing interest rates, banks with positive gap need to think about lowering the RSA by means of managing their assets, such as banks need to buy long-term securities; extend the loan maturity; and change the interest rate from a floating rate to a fixed rate. In terms of management liabilities, banks with positive gap need to think about increasing RSL by giving premium interest rates for deposits with a maturity of less than one year; and by borrowing funds at fair interest rates.

Implications for future research, it is necessary to improve weaknesses in this study, namely measuring variable not based on NII nominal value, but based on ratio measurement, for example, NIM or NII divided by total assets or NII divided by total funds collected from the third parties. To avoid homogeneity problems, it is also necessary to classify banks based on their total assets to see how NII of different total asset groups.

\section{REFERENCES}

Acharya, V. V., Cooley, T. F., Richardson, M., Walter, I. (2011). Regulating wall street: The Dodd-Frank Act and the new architecture of global finance. New Jersey: John Wiley \& Sons Inc.

Ahmed, A. S., Beatty, A., Takeda, C. (1997). Evidence on interest rate risk management and derivatives usage by commercial banks. Retrieved from https://ssrn.com/abstract=33922 doi:http://dx.doi.org/10.2139/ssrn.33922

Ali, M. (2004). Asset-liability management: menyiasati risiko pasar dan risiko operasional dalam perbankan. Jakarta: Elex Media Komputindo

Bank Indonesia. (2001). Laporan keuangan publikasi triwulanan dan bulanan bank umum serta laporan tertentu yang disampaikan kepada Bank Indonesia, Surat Edaran Bank Indonesia No. 3/30/DPNP C.F.R. Retrieved from https://www.bi.go.id/id/peraturan/arsipperaturan/Perbankan2001/SE\%20Lap.publikasi.PDF

Bank Indonesia. (2017). Statistik perbankan Indonesia. Retrieved from http://www.bi.go.id//statistikperbankanindonesia/

Baser, N. (2014). Asset and liability management of scheduled commercial banks. International Journals of Marketing and Technology, 2(4), 20-44. https://www.ijmra.us/project\%20doc/IJMT_APRIL2012/IJMRA-MT732.pdf

BPS. (2017). Realisasi investasi penanaman modal dalam negeri menurut sektor ekonomi. Retrieved from https://www.bps.go.id/statictable/2014/01/15/1317/realisasi-investasi-penanaman-modal-dalam-negeri-menurut-sektor-ekonomi-fontclass-font922802-sup-1-sup-font-font-class-font822802-miliar-rupiah-2000-2016.html

Budoyo, W. (2017). Outlook ekonomi 2017: Ekonomi Indonesia memasuki fase pemulihan. Retrieved from https://www.btnproperti.co.id/blog/outlook-ekonomi-2017-ekonomi-indonesia-memasuki-fase-pemulihan-1145.html

Byrne, J., (2000), Bringing banking risk up to date. Balance Sheet. 8(6).

Djinarto, B. (2000). Banking asset liability management: Perencanaan, strategi, pengawasan, dan pengelolaan dana. Jakarta: Gramedia Pustaka Utama.

Djohanputro, B. (2004). Manajemen risiko korporat terintegrasi. Jakarta: PPM 
Doran, D., Fitzpatrick, T. (2003). The Irish banking sector: An overview and some future trends. Ireland: Central Bank and Financial Services Authority of Ireland. Retrieved from http://www.bankinginquiry.gov.ie/the\%20irish\%20banking\%20crisis\%20regulatory\%20and\%20financial\%20stability\%20policy\%2020032008.pdf

Esposito, L., Nobili, A., Ropele, T. (2015). The management of Interest rate risk during the crisis: Evidence from Italian banks. Journal of Banking \& Finance, 59, 486-504. https://doi.org/10.1016/j.jbankfin.2015.04.031

Ghozali, I. (2013). Aplikasi analisis multivariate dengan program SPSS (9 ed.). Semarang: Badan Penerbit Universitas Diponegoro.

Hair Jr., J. F., Black, W. C., Babin, B. J., Anderson, R. E. (2010). Multivariate data analysis: A global perspective. 7th Edition, Pearson Education, Upper Saddle River

Holston, K., Laubach, T., Williams, J. C. (2017). Measuring the natural rate of interest: International trends and determinants. Journal of International Economics, 108(Supplement), S59-S75. DOI: https://doi.org/10.1016/j.jinteco.2017.01.004

J.P.Morgan. (1997). Credit metrics-technical document. New York.

Kementerian Dalam Negeri. (2017). Modul penilaian kinerja badan usaha milik daerah. Jakarta: Kementerian Dalam Negeri.

Koch, T. W., Macdonald, S. S. (2003). Bank management (5 ed.). Ohio: Thomson South-Western.

Kuncoro, M., Suhardjono. (2004). Manajemen perbankan. Yogyakarta: BPFE.

Meena, A. K., Dhar, J. (2014). empirical analysis and comparative study of liquidity ratios and asset-liability management of banks operating in India. International Journal of Social, Human Science and Engineering. 8, 358-363. https://www.waset.org/publications/9997584

Mishkin, F. S., Eakins, S. G. (2012). Financial markets and Institutions (Global Edition ed.). Essex: Pearson Education Limited.

Murphy, E. V. (2013). Who regulates whom and how? An overview of U.S. financial regulatory policy for banking and securities markets. Washington, DC: Congressional Research Service. Retrieved from https://digitalcommons.ilr.cornell.edu/cgi/viewcontent.cgi?article=2154\&context=key workplace

OJK. (2017a). Indonesian banking statistics. Retrieved from http://www.ojk.go.id/id/kanal/perbankan/data-dan-statistik/statistikperbankan-indonesia/Documents/OJKSPIDes2013 1392786491.pdf

OJK. (2017b). Penilaian tingkat kesehatan bank umum. Retrieved from https://www.ojk.go.id/id/kanal/perbankan/regulasi/surat-edaranojk/Pages/Surat-Edaran-Otoritas-Jasa-Keuangan-Nomor-14-SEOJK.03-2017.aspx

Prathap, B. N. (2013). An empirical study of asset liability management by indian banks. Asia Pacific Journal, 2(4), 1-10.

Rachel, L., Smith, T. D. (2015). Secular drivers of the global real interest rate. Staff Working Paper ( ed.): Bank of England

Riyadi, S. (2006). Banking asset and liability management (3 ed.). Jakarta: Lembaga Penerbit Fakultas Ekonomi Universitas Indonesia.

Siamat, D. (2004). Manajemen lembaga keuangan (4 ed.). Jakarta: Lembaga Penerbit Fakultas Ekonomi Indonesia.

Singh, K. (2013). Asset-liability management in banks: A dynamic approach. Journal of Management \& Research, 7(2/4).

Vij, M. (2005). Managing gap: A case study approach to asset-liability management of banks. Visıon-The Journal of Business Perspective, 9(1), 49-58.

Winarso, E., Salim, I. A. (2017). The Influence of risk management to the return on asset (ROA) banking sector (Case Study of Bank in Indonesia Listed in Indonesia Stock Exchange). Advances in Economics and Business, 5(7), 382-393. 


\section{Appendix: Results of Classical Assumption Tests}

\section{Normality Test}

\begin{tabular}{|l|c|c|c|c|c|c|}
\hline \multirow{2}{*}{} & \multicolumn{3}{|c|}{ Kolmogts of Normality } \\
\cline { 2 - 7 } & Statistic & df & Sig. & Statistic & df & Sig. \\
\hline Unstandardized Residual & .029 & 285 & $.200^{*}$ & .995 & 285 & .443 \\
\hline
\end{tabular}

*. This is a lower bound of the true significance.

a. Lilliefors Significance Correction

Kolmogorov-Smirnov and Shapiro-Wilk test provide significance value more than 0.05 . Hence, it can be concluded that the residual is normally distributed.

\section{Heteroscedasticity Test}

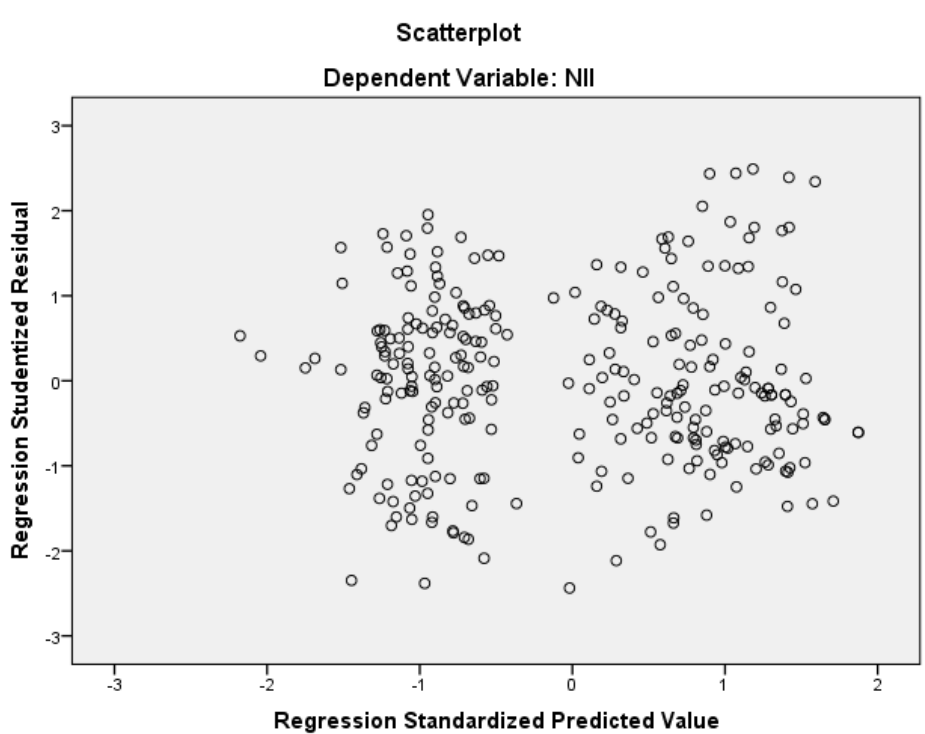

Based on the graph that the graph does not have a certain pattern and the dot is scattered randomly. Hence, there is no heteroscedasticity issue.

\section{Multicollinearity Test}

Multocollinearity problem can be checked from the value of VIF. Multicollinearity occurred when the value of the VIF is more than 10 . The following table provides the result of multicollinearity test.

\section{Coefficients $^{\mathrm{a}}$}

\begin{tabular}{|c|c|c|c|c|c|c|c|c|c|c|}
\hline \multirow{2}{*}{\multicolumn{2}{|c|}{ Model }} & \multicolumn{2}{|c|}{$\begin{array}{l}\text { Unstandardized } \\
\text { Coefficients }\end{array}$} & \multirow{2}{*}{$\begin{array}{c}\begin{array}{c}\text { Standardized } \\
\text { Coefficients }\end{array} \\
\text { Beta } \\
\end{array}$} & \multirow{2}{*}{$\mathrm{t}$} & \multirow{2}{*}{ Sig. } & \multicolumn{2}{|c|}{$\begin{array}{l}90.0 \% \text { Confidence } \\
\text { Interval for B }\end{array}$} & \multicolumn{2}{|c|}{$\begin{array}{l}\text { Collinearity } \\
\text { Statistics }\end{array}$} \\
\hline & & B & $\begin{array}{l}\text { Std. } \\
\text { Error }\end{array}$ & & & & $\begin{array}{l}\text { Lower } \\
\text { Bound }\end{array}$ & $\begin{array}{l}\text { Upper } \\
\text { Bound }\end{array}$ & Tolerance & VIF \\
\hline & (Constant) & 26.639 & 1.185 & & 22.472 & .000 & 24.682 & 28.595 & & \\
\hline & IRS & -.413 & .224 & -.087 & -1.844 & .066 & -.782 & -.043 & .828 & 1.207 \\
\hline & GAP & .295 & .150 & .089 & 1.959 & .051 & .046 & .543 & .899 & 1.112 \\
\hline & NPL & .096 & 1.102 & .004 & .087 & .931 & -1.722 & 1.914 & .964 & 1.038 \\
\hline & LDR & .884 & .500 & .083 & 1.766 & .079 & .058 & 1.710 & .822 & 1.217 \\
\hline & PRIVATE & -2.025 & .144 & -.732 & -14.052 & .000 & -2.263 & -1.787 & .676 & 1.480 \\
\hline & FOREIGN & -.689 & .157 & -.224 & -4.377 & .000 & -.948 & -.429 & .700 & 1.429 \\
\hline & Y2014 & .156 & .187 & .045 & .834 & .405 & -.153 & .465 & .624 & 1.602 \\
\hline & Y2015 & .311 & .188 & .090 & 1.660 & .098 & .002 & .621 & .621 & 1.609 \\
\hline & Y2016 & .512 & .188 & .148 & 2.729 & .007 & .202 & .822 & .621 & 1.611 \\
\hline & Y2017 & .677 & .189 & .196 & 3.582 & .000 & .365 & .988 & .612 & 1.633 \\
\hline
\end{tabular}


a. Dependent Variable: NII

About the value of VIF, there is no VIF more than 10 so that it can be concluded that there is no multicollinearity.

4. Autocorrelation Test

Model Summary

\begin{tabular}{|l|r|r|r|r|r|}
\hline Model & R & R Square & Adjusted R Square & Std. Error of the Estimate & Durbin-Watson \\
\hline 1 & $.705^{\mathrm{a}}$ & .497 & .479 & .99831365 & 2.127 \\
\hline
\end{tabular}

a. Predictors: (Constant), Y2017, FOREIGN, NPL, IRS, Y2014, GAP, LDR, Y2015, PRIVATE, Y2016

b. Dependent Variable: NII

$\mathrm{N} \quad: \quad 285$

K : 10

$\mathrm{Du} \quad: \quad 1.834105$

DL : 1.70423

DW : 2.127

If Dw $>$ Du there is no positive autocorrelation. The result is that $D w=2.127>D u=1.834105$. If $(4-D w)>D u$ there is no negative autocorrelation. The result is that $1.873>\mathrm{Du}=1.834105$. Hence, there is no autocorrelation issue. 